\title{
Performance Evaluation of Molecularly Imprinted Polymer using Propanol as Porogen for Atenolol Recognition in Human Serum
}

\author{
Meilia Suherman, Ike Susanti, Driyanti Rahayu, Rimadani Pratiwi, Aliya N. Hasanah* \\ Departemen Analisis Farmasi dan Kimia Medisinal, Fakultas Farmasi, Universitas \\ Padjadjaran, Jawa Barat - Indonesia
}

Submitted 12 September 2018; Revised 24 September 2018; Accepted 26 September 2018; Published 11 February 2019

*Corresponding author: aliya.n.hasanah@unpad.ac.id

\begin{abstract}
Atenolol is a cardiovascular drug that has a narrow therapeutic index with long-term use and it's often used as doping. Atenolol has a small concentration in human body and it's in biological matrix (serum) so in the testing need a selective extraction so the analyte can be pra-concentration and removed from matrix. Two molecularly imprinted polymers (MIPs) on propanol as porogen have been made with two different methods i.e. bulk polymerization and precipitation polymerization. The polymer was made using atenolol as a template, methacrylic acid as a functional monomer, and ethylene glycol dimethacrylate as a crosslinker. Performance evaluations showed that polymers from bulk polymerization provide better performance than polymers from precipitation polymerization when tested against standard solution. However, this sorbent has low recovery percentage after applied into serum sample and could not be used as alternative for atenolol extraction in human serum.
\end{abstract}

Keywords: Atenolol, molecularly imprinted polymer, preparation method, propanol, solid phase extraction.

\section{Evaluasi Kinerja Molekular Imprinting Polimer dengan Porogen Propanol untuk Pengenalan Atenolol dalam Serum}

\begin{abstract}
Abstrak
Atenolol merupakan obat kardiovaskular yang memiliki indeks terapi sempit dengan pemakaian jangka panjang dan sering disalahgunakan sebagai doping. Atenolol dalam tubuh memiliki kadar yang kecil dan berada dalam matrik biologis (serum) sehingga dalam pengujiannya diperlukan ekstraksi yang selektif sehingga analit dapat diprakonsetrasikan dan matriks sampel dihilangkan. Telah dibuat dua jenis Molecular Imprinted Polimer (MIP) atenolol dalam propanol sebagai porogen dengan dua metode berbeda yaitu polimerisasi ruah dan polimerisasi pengendapan. Polimer dibuat dengan menggunakan atenolol sebagai template, asam metakrilat sebagai monomer fungsional, dan etilen glikol dimetakrilat sebagai crosslinker. Evaluasi kinerja menunjukan polimer yang dibuat dengan polimerisasi ruah memberikan kinerja yang lebih baik dari polimer yang dibuat dengan polimerisasi pengendapan ketika diujikan dengan larutan standar. Namun, sorben ini memiliki persentase perolehan kembali yang rendah setelah diaplikasikan ke dalam sampel serum dan tidak dapat digunakan sebagai alternatif untuk ekstraksi atenolol dalam serum.
\end{abstract}

Kata Kunci: Atenolol, ekstraksi fase padat, molecular imprinted polymer, metode preparasi, propanol. 


\section{Pendahuluan}

Atenolol merupakan obat sintesis golongan $\beta$-bloker yang digunakan untuk pengobatan penyakit kardiovaskular. ${ }^{1}$ Namun, atenolol sering disalahgunakan sebagai doping bagi atlet karena memiliki efek yang dapat mengurangi tekanan darah sistolik dan diastolik. $^{2}$

Terdapat banyak metode pengujian untuk atenolol. Namun, metode-metode yang digunakan memiliki kelemahan dari sisi biaya yang tinggi untuk mendapatkan sensitivitas yang baik. Oleh karena itu, perlu dikembangkan metode preparasi yang spesifik sehingga analisis atenolol dapat dilakukan dengan instrumentasi Kromatografi Cair Kinerja Tinggi (KCKT) detektor UV yang umum ada di laboratorium-laboratorium pengujian.

Saat ini, berkembang preparasi sampel dengan menggunakan Solid Phase Extraction (SPE) yang spesifik, yaitu melalui pembentukan Molecularly Imprinted Polymer (MIP). Penggunaan metode preparasi ini, diharapkan dapat mengurangi beberapa kelemahan di atas. Metode preparasi MIP ini memungkinkan penetapan kadar analit yang dapat dilakukan dengan penggunaan KCKT yang umum terdapat di setiap institusi.

Pada pembuatan MIP banyak hal yang harus dipertimbangkan, seperti pemilihan monomer, crosslinker dan porogen. ${ }^{3}$ Pemilihan porogen yang tepat akan mempengaruhi kinerja dari sorben. Polaritas porogen berpengaruh besar pada formasi struktur sorben yang dibentuk. Porogen yang polar akan berinteraksi secara berkompetitif dengan template ataupun dengan monomer, sementara porogen non polar kurang berinteraksi dengan template ataupun dengan monomer. ${ }^{4}$

Penggunaan porogen metanol dengan monomer asam metakrilat telah dilakukan pada penelitian sebelumnya dan memberikan hasil perolehan kembali yang baik untuk penetapan kadar atenolol dalam serum, tetapi nilai imprinting factor dari MIP yang dihasilkan masih rendah. ${ }^{5}$

Oleh karena itu penelitian ini dilakukan untuk membuat MIP yang selektif terhadap atenolol dengan menggunakan pelarut propanol yang lebih non polar dibandingkan metanol agar dapat memfasilitasi terbentuknya ikatan hidrogen sebagai dasar interaksi monomer-template pada MIP.

\section{Metode}

2.1. Alat

Kromatografi Cair Kinerja Tinggi (KCKT) (Dionex Ultimate 3000), kolom LiChrospher ${ }^{\circledR} 100$ RP-18 (Merck) dengan panjang kolom 250x4,0 $\mathrm{mm}$, cartridge SPE (Supelco column SPE superclean LC$\mathrm{Si}$ ), ayakan mesh 60, Fourier Transform Infrared (FTIR) (Shimadzu, IR Prestige-21), oven (Memmert), Scanning Electron Microscope (SEM) (JEOL JSM-6360 LA), spektrofotometer UV-Vis (Analytik jena, specord 2000), sentrifugasi (Yenaco dan Hettich), timbangan digital (Ohaus pioneer), ultrasonik (NEY 1510), waterbath (Memmert) dan alat-alat gelas yang umum digunakan di laboratorium.

\subsection{Bahan}

Asam asetat (Merck), asam metakrilat (Sigma Aldrich), asetonitril HPLC gradient grade (Fisher Scientific), atenolol (TCI), trietilenamina (Sigma-Aldrich), asam triflouroamin (Sigma-Aldrich), benzoil peroksida, EGDMA(Aldrich), metanol HPLC gradient grade (Fisher Scientific), metaprolol (TCI), propanol (Merck), propanolol hidroklorida (TCI).

\subsection{Penentuan Konstanta Asosiasi Monomer-Template \\ Larutan atenolol $2 \times 10^{-5} \mathrm{M}$ dalam} propanol diukur serapannya menggunakan spektofotometer UV. Kemudian, ditambahkan asam metakrilat $5 \times 10^{-3} \mathrm{M}$ sedikit demi sedikit. Setiap penambahan asam metakrilat diukur serapannya dan kemudian dihitung konstanta asosiasinya. menggunakan persamaan Benesi-Hildebran :

$$
\frac{1}{\Delta \mathrm{Y}}=\frac{1}{\mathrm{Y} \Delta \mathrm{HGKa}[\mathrm{G}]}+\frac{1}{\mathrm{Y} \Delta \mathrm{HG}}
$$

Dimana, $\Delta Y$ merupakan perubahan absorbansi, Y $\Delta \mathrm{HG}$ merupakan perubahan 
absorbansi dengan absorbansi dititik akhir titrasi, Ka merupakan konstanta asosiasi, dan [G] merupakan konsentrasi monomer yang ditambahkan. ${ }^{6}$

\subsection{Sintesis Molecular Imprinted Polymer} Sintesis Molecular Imprinted Polymer dilakukan dengan menggunakan metode polimerisasi ruah dan polimerisasi pengendapan dengan menggunakan porogen propanol.

\subsection{Sintesis MIP dengan Metode Polimerisasi Ruah \\ Atenolol (template) 0,2663 g dilarutkan} dalam $10 \mathrm{~mL}$ propanol dalam vial tertutup dan disonikasi selama 5 menit hingga atenolol larut. Monomer asam metakrilat (monomer fungsional) sebanyak $340 \mu \mathrm{L}$ ditambahkan dan disonikasi selama 20 menit. EGDMA (cross linker) 3,77 $\mathrm{mL}$ ditambahkan dan disonikasi selama 5 menit. Benzoil peroksida sebagai inisiator sebanyak $250 \mathrm{mg}$ ditambahkan dan disonikasi selama 20 menit (hingga larut). Vial diseal dengan menggunakan parafilm dan dipanaskan di dalam oven selama 1 jam dengan suhu $70^{\circ} \mathrm{C}$. Vial kemudian dipindahkan ke dalam waterbath dengan suhu $70^{\circ} \mathrm{C}$ selama 18 jam. Polimer yang terbentuk dihancurkan dan diayak dengan mesh 60 . Polimer dicuci dengan menggunakan $20 \mathrm{~mL}$ metanol, setelah itu polimer dikeringkan dalam oven dengan suhu $50^{\circ} \mathrm{C}$. Kemudian, polimer diekstraksi menggunakan soklet selama 24 jam dengan pelarut metanol : asam asetat (9:1). Setelah diekstraksi dengan soxhlet, sorben dikeringkan di dalam oven selama 18 jam dengan suhu $50^{\circ} \mathrm{C}$. Monitoring dengan spektrofotometer UV dilakukan untuk memastikan atenolol telah terekstraksi sempurna. Selain MIP, dibuat juga Non Imprinted Polimer (NIP) dengan prosedur yang sama tanpa adanya penambahan atenolol (template).

\subsection{Sintesis Polimer MIP-SPE dengan} Metode Polimerisasi Pengendapan

Atenolol (template) 0,2663 g dilarutkan dalam $50 \mathrm{~mL}$ propanol dalam botol kaca tertutup dan disonikasi hingga atenolol larut. Monomer asam metakrilat (monomer fungsional) sebanyak $340 \mu \mathrm{L}$ dan $300 \mathrm{~mL}$ propanol ditambahkan dan disonikasi selama 20 menit. EGDMA (cross linker) 3,77 mL ditambahkan dan disonikasi selama 5 menit. Benzoil peroksida sebagai inisiator sebanyak $250 \mathrm{mg}$ ditambahkan dan disonikasi selama 20 menit (hingga larut). Botol diseal dengan menggunakan parafilm dan dipanaskan di dalam oven selama 1 jam dengan suhu $70^{\circ} \mathrm{C}$. Vial kemudian dipindahkan ke dalam waterbath shaker dengan suhu $70^{\circ} \mathrm{C}$ selama 18 jam. Polimer disaring dan dicuci dengan menggunakan $40 \mathrm{~mL}$ metanol, setelah itu polimer dikeringkan dalam oven dengan suhu $50^{\circ} \mathrm{C}$. kemudian polimer diekstrasi dengan prodsedur yang sama seperti metode ruah. Selain MIP, dibuat juga Non Imprinted Polimer (NIP) dengan prosedur yang sama tanpa adanya penambahan atenolol (template).

\subsection{Evaluasi Kemampuan Adsorpsi MIP-} SPE dan NIP-SPE

Atenolol 5 ppm dibuat dalam berbagai macam pelarut, metanol, asetonitril dan metanol : asetonitril (1:1). $5 \mathrm{~mL}$ larutan atenolol 5 ppm ditambahkan ke dalam vial yang berisi $20 \mathrm{mg}$ sorben MIP, kemudian dilakukan shaking selama 5 menit dan didiamkan selama 24 jam. Campuran selanjutnya didekantasi dan dilakukan pengukuran absorbansi filtrat menggunakan spektrofotometer UV. Jumlah atenolol yang terabsorpsi dihitung berdasarkan selisih konsentrasi awal atenolol dan konsentrasi atenolol akhir dalam filtrat. Evaluasi ini dilakukan pula pada NIP dengan metode yang sama.

\subsection{Evaluasi Kapasitas Adsorpsi MIP-SPE dan NIP-SPE}

Konsentrasi larutan atenolol yaitu 2,$5 ; 5 ; 7,5 ; 10,12,5$ dan 15 ppm disiapkan. Sebanyak $5 \mathrm{~mL}$ larutan atenolol 7,5; 10 dan 12,5 ppm dimasukkan ke dalam vial yang berisi $20 \mathrm{mg}$ sorben MIP metode ruah serta 2,5; 10, 15 ppm dimasukkan ke dalam vial yang berisi $20 \mathrm{mg}$ sorben MIP metode pengendapan. Kemudian dilakukan shaking selama 5 menit dan didiamkan selama 24 
jam. Campuran selanjutnya didekantasi dan dilakukan pengukuran absorbansi filtrat menggunakan spektrofotometer UV. Jumlah atenolol yang terabsorpsi dihitung berdasarkan selisih konsentrasi awal atenolol dan konsentrasi atenolol akhir dalam filtrat. Evaluasi ini dilakukan pula pada NIP dengan metode yang sama.

\subsection{Penentuan Selektivitas MIP dan NIP} Penetapan selektivitas dilakukan dengan penambahan larutan analog atenolol di antaranya metaprolol dan propranolol. 5 $\mathrm{mL}$ larutan konsentrasi 5 ppm dari masingmasing larutan zat dimasukkan ke dalam vial berbeda yang telah berisi $20 \mathrm{mg}$ sorben MIP kemudian dilakukan shaking selama 5 menit dan didiamkan selama 24 jam. Campuran selanjutnya didekantasi dan dilakukan pengukuran absorbansi filtrat menggunakan spektrofotometer UV.

\subsection{Karakterisasi Fisik}

Pengujian karakterisasi fisik polimer dilakukan dengan pegujian FTIR dan Scanning Electron Microscope (SEM).

\subsection{Optimasi sistem SPE}

Sebanyak 200 mg MIP dan NIP di packing ke dalam cartridge. Kemudian, dilakukan optimasi pelarut yang digunakan untuk conditioning, loading, washing, dan eluting.
2.12. Aplikasi MIP-SPE untuk Ekstraksi Atenolol dalam Sampel Serum

Serum darah didapatkan dengan mensentrifugasi darah dengan kecepatan $5000 \mathrm{rpm}$ selama 5 menit, kemudian diambil bagian atasnya. Serum darah di spike dengan 2 ppm atenolol dalam air. Serum yang telah di spike dilewatkan ke dalam MIP-SPE dan NIP-SPE. Sistem SPE dikondisikan dengan pelarut air, pelarut pencuci menggunakan asetonitril dan pengelusi menggunakan metanol : asam triflouroasetat 0,05\% (99:1). Hasil elusi kemudian dianalisis dengan KCKT dengan menggunakan fase gerak metanol : air + TEA 0,05\% yang di adjust pH 3 dengan asam fosfat (15:85). Kemudian hasil perolehan kembali dihitung.

\section{Hasil}

Hasilpengujian secara spektrofotometri, menunjukkan bahwa terjadi pembentukan ikatan kimia yang baru di antara asam metakrilat dan atenolol seiring penambahan asam metakrilat (Gambar 1). Penetapan konstanta asosiasi yang diperoleh dengan memplotkan nilai $1 / \Delta \mathrm{Y}$ dengan $1 /[\mathrm{G}]$ sesuai adalah 5,1x102 M.

Sorben MIP metode ruah memiliki kemampuan adsorpsi pada pelarut metanol sedangkan MIP metode pengendapan pada pelarut campur metanol : asetonitril $(1: 1)$. kemampuan adsorpsi MIP dengan metode ruah sebesar $64,95 \%$ pada pelarut metanol

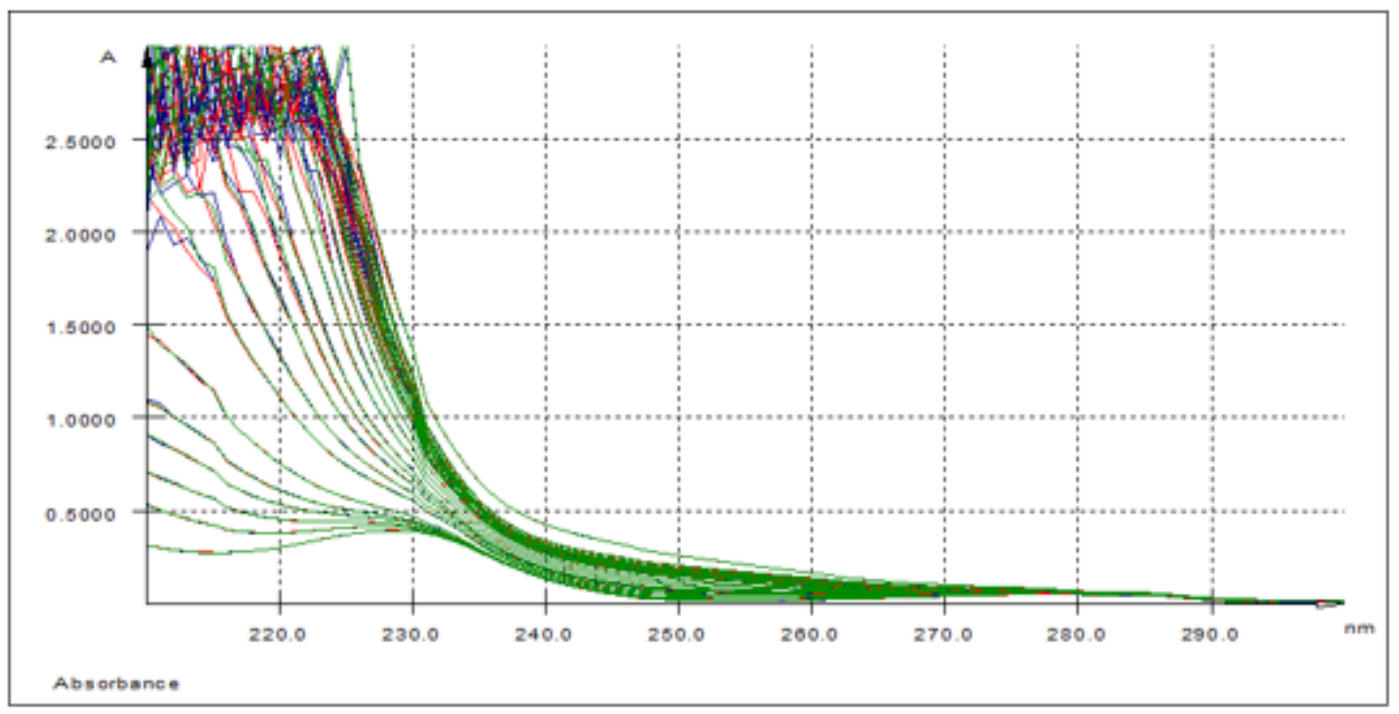

Gambar 1. Spektrum absorpsi UV atenolol dengan monomer asam metakrilat menggunakan pelarut propanol 
dan MIP dengan metode pengendapan sebesar $65,44 \%$ pada pelarut campuran metanol : asetonitril (1:1). Kemampuan adsorbsi MIP atenolol baik dengan metode pengendapan maupun metode ruah dalam pelarut asetonitril mencapai $100 \%$ (Gambar 2).

Tabel 1 menunjukkan hasil evaluasi kemampuan absorbsi sorben MIP metode ruah memiliki afinitas dan homogenitas yang lebih baik (nilai $\mathrm{m}=1,1817$ dan $\mathrm{a}=0,1043$ ) dibandingkan dengan sorben MIP metode pengendapan (nilai $\mathrm{m}=0,4702$ dan $\mathrm{a}=$ 0,0804) .

Hasil penentuan imprinting factor MIP untuk atenolol $(11,721)$ menunjukkan nilai yang lebih besar dibandingkan senyawa analognya (metoprolol : 1,535 dan propranolol : 0,163), terlihat pada Tabel 2 .

Gambar 3 menunjukkan hasil karakterisasi fisik dengan FTIR yang menunjukkan adanya pergeseran pada area $-\mathrm{OH}$ stretching dan area $\mathrm{C}=\mathrm{O}$ stretching, yang menunjukkan adanya pembentukan ikatan baru setelah dilakukan proses ekstraksi atenolol.

Hasil pengamatan secara mikroskopik dengan SEM, diperoleh bahwa ukuran ratarata partikel dari sorben MIP adalah 0,439 $\mu \mathrm{m}$ dan NIP adalah 0,429 $\mu \mathrm{m}$ (Gambar 4).

Nilai perolehan kembali untuk serum yang telah di spike dengan atenolol adalah $35,47 \%$ dan $66,54 \%$ untuk NIP Ruah dan MIP
Ruah, dan 47,83\% dan 10,86\% untuk NIP Pengendapan dan MIP Pengendapan.

\section{Pembahasan}

4.1. Hasil Penentuan Konstanta Asosiasi Larutan atenolol $2 \times 10^{-5} \mathrm{M}$ dalam propanol diukur serapannya menggunakan spektofotometer UV pada panjang gelombang 220-300 nm. Panjang gelombang maksimal yang diperoleh adalah $228 \mathrm{~nm}$. Asam metakrilat $5 \times 10^{-3} \mathrm{M}$ kemudian ditambahkan sedikit demi sedikit. Setiap penambahan asam metakrilat diukur serapannya dan kemudian dihitung konstanta asosiasinya menggunakan persamaan Benesi-Hildebran dengan membuat kurva hubungan antara $1 / \Delta \mathrm{Y}$ dengan $1 /[\mathrm{G}] .^{6}$

Gambar 1 menunjukan terjadinya kenaikan absorbansi di panjang gelombang maksimal $228 \mathrm{~nm}$ dengan adanya penambahan asam metakrilat yang menunjukkan bahwa terjadinya ikatan kimia yang baru di antara asam metakrilat dan atenolol ${ }^{4}$, yaitu ikatan non kovalen (ikatan hidrogen). Hal ini menunjukkan bahwa gugus fungsi asam karboksilat dari monomer asam metakrilat dapat bertindak sebagai donor proton. Nilai konstanta assosiasi yang ditentukan dari slope garis lurus dari plot antara $1 / \Delta$ terhadap $1 /$ [asam metakrilat] adalah $5,1 \times 10^{2} \mathrm{M}-1$. yang menunjukkan adanya kekuatan ikatan antara monomer fungsional dengan template. ${ }^{7}$

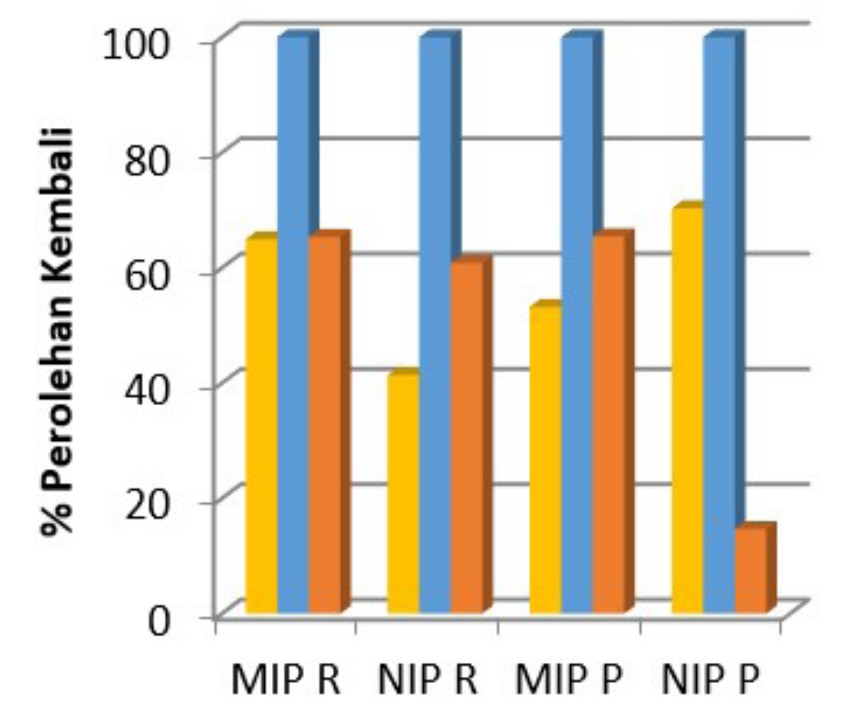

Metanol

Asetonitril

Metanol : Asetonitril

Gambar 2. Kemampuan adsorpsi MIP dan NIP pada beberapa pelarut (P : Pengendapan, R : Ruah) 
Tabel 1. Parameter Freundlich Sorben MIP dan NIP

\begin{tabular}{ccccc}
\hline Polimer & Metode & $\mathrm{R}$ & $\mathrm{M}$ & $\mathrm{a}(\mathrm{mg} / \mathrm{g})$ \\
\hline MIP & Ruah & 0,6446 & 1,1817 & 0,1043 \\
NIP & Ruah & 0,875 & 1,4029 & 1,0204 \\
MIP & Pengendapan & 0,8175 & 0,4702 & 0,0804 \\
NIP & Pengendapan & 0,5827 & 0,4529 & 0,0978 \\
\hline
\end{tabular}

4.2. Evaluasi Kemampuan Adsorpsi MIP dan NIP-SPE

Gambar 2 menunjukkan kemampuan adsorpsi dari MIP yang dibuat dengan polimerisasi ruah dan pengendapan. Kemampuan adsorpsi MIP dengan metode ruah sebesar $64,95 \%$ pada pelarut metanol dan MIP dengan metode pengendapan $65,44 \%$ pada pelarut campuran metanol : asetonitril (1:1). Kemampuan adsorbsi dari MIP atenolol baik dengan metode pengendapan maupun metode ruah dalam pelarut asetonitril mencapai $100 \%$.

\subsection{Evaluasi Kapasitas Adsorpsi MIP dan NIP}

Evaluasi kapasitas adsorpsi dihitung dengan menggunakan persamaan Isoterm Freudlich untuk menentukan afinitas, ukuran kapasitas dan indeks heterogenitas dari polimer. $^{8}$

Tabel 1 menunjukkan bahwa ditribusi situs pengikatan pada MIP dan NIP metode ruah lebih homogen dikarenakan nilai $\mathrm{m}$ lebih mendekati 1 . Nilai $\mathrm{m}$ yang mendekati satu mengindikasikan sistem telah homogen (9). Pada Tabel 1, MIP metode pengendapan memiliki nilai afinitas terhadap atenolol yang lebih kecil dibandingkan dengan MIP metode ruah. Hal ini dapat disebabkan pada MIP metode pengendapan memiliki distribusi daerah pengikatan tidak menyebar secara merata berdasarkan nilai $m$ yang lebih kecil dari satu. Distribusi daerah pengikatan yang tidak merata dapat mengakibatkan kemampuan adsorpsi tiap sisi dalam sorben berbeda-beda. Tabel 1 menunjukan afinitas NIP metode ruah memiliki nilai yang lebih besar dibandingkan dengan MIP. Hal ini kemungkinan disebabkan heterogenisitas NIP lebih besar sehingga kemampuan adsorpsi setiap sisi dalam sorben berbeda dan adanya perbedaan hasil dengan pengukuran kemampuan adsorpsi.

\subsection{Penentuan Selektivitas MIP dan NIP- SPE \\ Penentuan selektivitas dilakukan} dengan cara membandingkan nilai imprinting factor yang diperoleh dari atenolol dan obat beta bloker lainnya yang memiliki struktur dan sifat yang mirip dengan atenolol. Obat yang digunakan dalam adalah propranolol dan metoprolol. ${ }^{10}$

Imprinting factor (IF) diperoleh dari hasil perbandingan antara koefisien distribusi MIP dengan koefisien distribusi dari NIP. IF merupakan indikator untuk menentukan kualitas cetakan yang dihasilkan dalam mengenali template pada sorben MIP dan NIP. Berdasarkan Tabel 2, dapat diketahui bahwa nilai IF dari MIP baik metode pengendapan dan metode ruah menunjukkan bahwa MIP selektif terhadap atenolol. Nilai IF yang dihasilkan menunjukkan pula bahwa IF metoprolol lebih rendah dibandingkan dengan atenolol dan lebih tinggi dibandingkan propranolol. Hal ini dapat disebabkan karena

Tabel 2. Hasil Perhitungan Nilai KD dan IF

\begin{tabular}{|c|c|c|c|c|c|c|}
\hline \multirow{2}{*}{ Zat } & \multicolumn{4}{|c|}{$\mathrm{KD}$} & \multirow{2}{*}{ IF MIP * } & \multirow{2}{*}{ IF MIP** } \\
\hline & MIP* & NIP* & MIP** & NIP ** & & \\
\hline Atenolol & 500,87 & 174,42 & 494,48 & 42,19 & 2,872 & 11,721 \\
\hline Metoprolol & 79,95 & 89,21 & 75,62 & 53,03 & 0,896 & 1,535 \\
\hline Propranolol & 62,76 & 132,40 & 135,21 & 829,27 & 0,474 & 0,163 \\
\hline
\end{tabular}




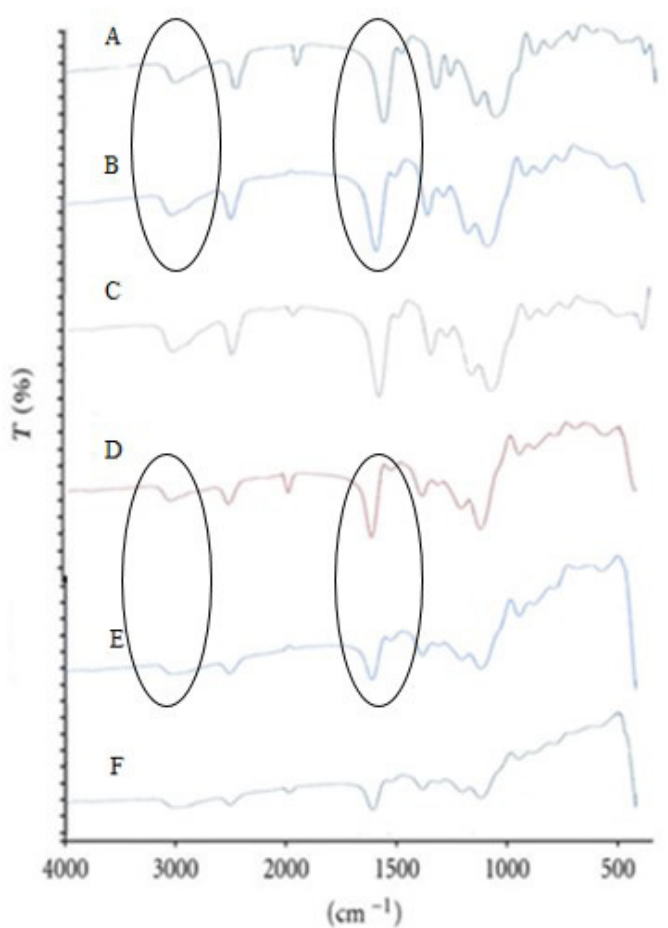

Gambar 3. Spektrum FTIR sorben hasil polimerisasi ruah (A:MIP pengendapan sebelum ekstraksi, B : MIP pengendapan setelah ekstraksi, C : NIP pengendapan, D:MIP ruah sebelum ekstraksi, $\mathrm{E}:$ MIP ruah setelah ekstraksi, $\mathrm{F}$ : NIP ruah)

struktur subtituen dari cincin aromatik dari metoprolol dan atenolol memiliki kemiripan yang lebih besar dibandingkan dengan propranolol.

\subsection{Karakterisasi Fisik Sorben}

Pengujian karakterisasi fisik sorben yang dihasilkan selanjutnya dilakukan

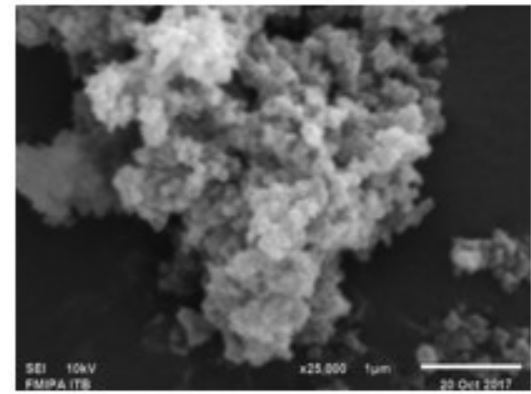

A

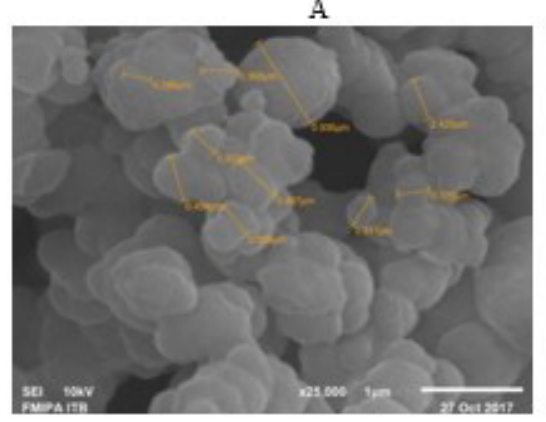

dengan menggunakan FTIR dilakukan pada MIP sebelum ekstraksi, NIP dan MIP setelah ekstraksi. Hasil karakterisasi polimer MIP metode pengendapan menggunakan FTIR menunjukkan adanya pergeseran bilangan gelombang pada MIP sebelum dan sesudah ekstraksi seperti terlihat pada Gambar 3. Pergeseran terjadi pada bilangan gelombang

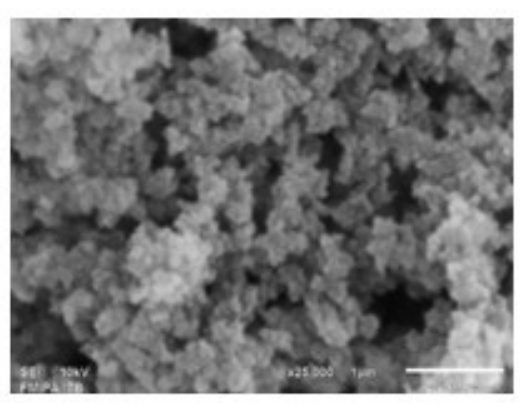

B

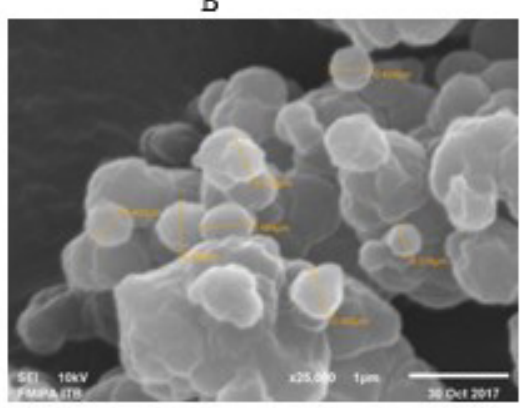

Gambar 4. Morfologi polimer yang diperoleh dengan Scanning Electron Microscope (A : MIP MAA Ruah Pelarut Propanol, B : NIP MAA Ruah Pelarut Propanol, C: MIP MAA Endapan Pelarut Propanol, D: NIP MAA Endapan Pelarut Propanol) 
$3577,05 \mathrm{~cm}^{-1}$ dan $1730,18 \mathrm{~cm}^{-1}$ sebelum ekstraksi dan pada $3589,91 \mathrm{~cm}^{-1}$ dan 1731,14 $\mathrm{cm}^{-1}$ setelah ekstraksi. Pergeseran ini menunjukkan adanya interaksi antara template dan monomer. Interaksi tersebut berupa ikatan hidrogen antara atenolol dan asam metakrilat menyebabkan terjadinya penurunan densitas elektron pada $-\mathrm{OH}$ dan $\mathrm{C}=\mathrm{O}$, sehingga terjadi reduksi frekuensi vibrasi. ${ }^{11}$

Untuk melihat bentuk mikroskopik dari polimer dilakukan dengan menggunakan SEM. Hasil pengujian SEM yang ditunjukkan pada Gambar 4 terlihat bahwa morfologi pada MIP metode ruah memiliki pori dan bentuk yang lebih homogen dibandingkan dengan NIP. Ukuran pori pada NIP relatif lebih besar, hal ini yang dapat menyebabkan pada percobaan Isoterm Freudlich memiliki nilai homogenitas yang rendah dibandingkan dengan NIP.

Hasil SEM dari MIP dan NIP metode pengendapan dapat dilihat pada Gambar 4. Ukuran partikel dari sorben MIP lebih heterogen dibandingkan dengan NIP. Ukuran rata-rata partikel dari sorben MIP dalah 0,439 $\mu \mathrm{m}$ dan NIP 0,429 $\mu \mathrm{m}$. Ukuran partikel yang lebih besar dapat mengakibatkan kemampuan adsorpsi dari polimeryang lebih rendah. Hal ini sesuai dengan hasil pengujian menggunakan Isoterm Freudlich bahwa afinitas MIP metode pengendapan lebih rendah dibandingkan dengan NIP-nya. ${ }^{4}$ Hal ini sesuai dengan hasil pengujian menggunakan Isoterm Freudlich bahwa afinitas MIP metode pengendapan lebih rendah dibandingkan dengan NIP-nya. ${ }^{4}$

\subsection{Aplikasi MIP-SPE pada Sampel Serum}

Sampel plasma yang telah di-spike dengan $2 \mathrm{ppm}$ atenolol memberikan nilai perolehan kembali $35,47 \%$ dan $66,54 \%$ untuk NIP R dan MIP R, dan 47,83\% dan 10,86\% untuk NIP P dan MIP P. Hal ini menunjukkan bahwa MIP yang dibuat dengan cara polimerisasi ruah lebih baik dibandingkan dengan pengendapan. Hal ini linier dengan hasil dari hasil SEM dan perhitungan afinitas. Tetapi nilai persen perolehan kembali yang diperoleh (FDA menetapkan bahwa nilai perolehan kembali berada pada kisaran 95.0\%-105.0\%) memperlihatkan bahwa sorben ini belum dapat digunakan sebagai alternatif material ekstraksi untuk atenolol dalam sampel serum. ${ }^{12}$

\section{Simpulan}

Pelarut propanol menghasilkan sorben yang selektif terhadap atenolol dibandingkan dengan analognya (metoprolol dan propranolol) pada saat diaplikasikan pada larutan standar. Namun, dari hasil aplikasi terhadap serum, sorben yang diperoleh memberikan nilai perolehan kembali di bawah persyaratan untuk perolehan kembali sampel biologis. Oleh karena itu, berdasarkan hasil penelitian ini sorben yang dihasilkan tidak dapat digunakan sebagai material ekstraksi atenolol dari sampel serum.

\section{Daftar Pustaka}

1. Damiani PC. Determination of atenolol in human urine by emission-excitation fluorescence matrices and unfolded partial least-squares with residual bilinearization. Talanta. 2011;85(3):1526-34.

2. Goryński K, Kiedrowicz A, Bojko B. Development of SPME-LC-MS method for screening of eight beta-blockers and bronchodilators in plasma and urine samples. J Pharm Biomed Anal. 2016;127:147-55.

3. Martín-Esteban A. Molecularly-imprinted polymers as a versatile, highly selective tool in sample preparation. TrAC - Trends Anal Chem. 2013;45(1):169-70.

4. Song S, Wu A, Shi X, Li R, Lin Z, Zhang D. Development and application of molecularly imprinted polymers as solid-phase sorbents for erythromycin extraction. Anal Bioanal Chem. 2008;390(8):2141-50.

5. Hasanah AN, Suryana S, Mutakin, Rahayu D. Different Polymerization Method for Atenolol Recognition in Human Plasma. 2017;29(11):2429-33.

6. Thordarson P. Determining association constants from titration experiments in supramolecular chemistry. Chem Soc Rev. 2011;40(3):1305-23.

7. Chen $\mathrm{CY}$, Wang $\mathrm{CH}$, Chen $\mathrm{AH}$. Recognition of molecularly imprinted 
polymers for a quaternary alkaloid of berberine. Talanta [Internet]. Elsevier B.V.; 2011;84(4):1038-46.

8. Ansel RJ. Induced pluripotent stem cell technology in regenerative medicine and biology. Springer Int Publ. 2015;123(July 2015):127-41.

9. Umpleby RJ, Baxter SC, Rampey AM, Rushton GT, Chen Y, Shimizu KD. Characterization of the heterogeneous binding site affinity distributions in molecularly imprinted polymers. J Chromatogr B Anal Technol Biomed Life Sci. 2004;804(1):141-9.

10. Storch $\mathrm{CH}$, Hoeger PH. Propranolol for infantile haemangiomas: Insights into the molecular mechanisms of action. $\mathrm{Br} \mathrm{J}$ Dermatol. 2010;163(2):269-74.

11. Shekarchi M, Pourfarzib M, AkbariAdergani B, Mehramizi A, Javanbakht M, Dinarvand R. Selective extraction of lamivudine in human serum and urine using molecularly imprinted polymer technique. J Chromatogr B Anal Technol Biomed Life Sci [Internet]. Elsevier B.V.; 2013;931:50-5.

12. FDA. Analytical Procedures and Methods Validation for Drugs and Biologics. Guid Ind. 2015;(July):1-15. 